\title{
THE CULTURE OF THE SAK TRIBES OF THE BRONZE AGE
}

\author{
Akhmadjon Shonazarovich Yusupov
}

Teacher, Faculty Of History, Urgench State University

Mohira Saparboy Qizi Abdullayeva

Student, Faculty Of History, Urgench State University

\section{ABSTRACT}

In this article is dedicated to the issue of the culture of the Sak tribes of the Bronze Age in Central Asia. The main attention is paid to the archeological investigations reflecting the culture of those tribes. At the same time, researches of historians on the theme has been analysed either. The expounded informations have been proved by the facts at the result of archeological expeditions.

KEYWORDS: - Saks, Aral Sea region, tribes, Tozaboghyob, Amirabad.

\section{INTRODUCTION}

It is important to identify aspects of the interdependence, harmony, and development of cultural traditions that continue on a new basis in different cultures of different periods. With this in mind, it is expedient to briefly review the content of the ancient traditions formed in the Aral Sea region.

\section{Literature review}

As a result of the study of archeological monuments of the Bronze Age of the Aral Sea region, various objects that make up the material culture were obtained. They have been adequately reviewed in the scientific literature [9].

During the Tozaboghyob and Amirabad periods, most of the settlements were located on the banks of the South Akchadarya River, as well as in the Jonidarya and Inkardarya oases, where seasonal livestock breeding took place. The composition of archeological materials consists of hand-made ceramic vessels decorated with geometric patterns and lines, bronze objects (knives, sickles, brass mirrors, bells, bracelets) and stone tools - scythes, hammers and sickles.

According to the main features, the Bronze Age population groups of the Aral Sea region have been identified as belonging to the steppe tribes. This is evidenced by their household items, weapons and accommodation. The dwellings were built in the form of a rectangular hut with a semi-basement, the upper sides and wooden columns at the top, covered with reeds at the base of lattice, i.e. they formed a system of columnar lattice light housing [6]. We see the method of construction of such dwellings in the repetition of the construction of houses of the first Iron Age Kuyisay culture.

V.M. Masson writes that settlements were associated with various aspects of the ancient 
CURRENT RESEARCH JOURNAL OF HISTORY 2(5): 42-46, May 2021

DOI: https://doi.org/10.37547/history-crjh-02-05-12

ISSN 2767-472X

(C)2021 Master Journals

\section{Crossref dof 81 Google}

Accepted 25th May, 2021 \& Published 30th May, 2021

social system. In their construction, along with household functions, socio-economic and environmental factors, the size of housing, building solutions and construction techniques found their will. Therefore, the housing system is defined by the leading sector of the economy and ethnic traditions. H. Matyakubov described socio-economic and territorial characteristics of the Bronze Age society. The Bronze Age of the Aral Sea region indicates once again that they were mainly cattle-breeders, according to the degree of reflection of socio-economic characteristics in the settlements of the tribes. The shepherds who grazed the cattle in the pastures used dwellings with a light construction structure. They created favorable living conditions for the population, who were engaged in cultivating the fields, growing fodder and stockpiling its reserves, as well as for hunters and fishermen. M.A. Itina described lifestyle and food culture of Bronze Age communities.

\section{Methods}

Comparing the lifestyle, socio-economic and territorial characteristics of the Bronze Age society, H. Matyakubov distinguished the following: the location of various seed communities in the region, common housing for large patriarchal families, property and food resources from existing natural resources in the region (water, land, meadows, flora and fauna, raw material resources) for development and production purposes [7].

In our opinion, it is expedient to expand the data in this place a little. During this period, every large family owned a pet. Meadows and pastures were probably used on a community basis. In addition to breeding small livestock and cattle, horse breeding and camel breeding became important branch of animal husbandry. Horses and camels played an important role in farm work and as means of hunting during the seasonal migration of shepherds. According to M.A. Itina, camel meat was almost never consumed in the diet of Bronze Age communities. Because the ability of this pet in the field of transportation and transport is appreciated. It is difficult to imagine the daily life of ancient steppe herders without domesticated animals such as camels, horses, and donkeys. Based on the traditions described above, we will consider aspects of the development of the material culture of the Early Iron Age in the Aral Sea region.

Livestock breeding provided shepherds with meat and dairy products, and played an important role in the trade of wool and leather, as well as in the manufacture of clothing, footwear, carpets, and household goods.

Analysis and results

As a result of the development of bronze metallurgy in the Aral Sea region during the Tozaboghyob culture, the demand for metals such as copper and tin gradually increased. As mentioned in the previous pages of the study, copper and tin deposits are located in the KyzylKum, adjacent to the Southern Urals, Central Kazakhstan and the Aral Sea region. According to the scientific literature, in the Bronze Age, copper and tin deposits were developed by steppe cattle-breeding tribes, and the raw materials obtained from them were smelted in special workshops around the ore deposits and cast metal pieces (ingots) were produced [8]. Those works was also carried out during the first Saks.

According to the materials of the tombs of Southern Tagisken, Uygarak, and Sakarchaga, the first Saks made extensive use of bronze knives, daggers, military axes, arrowheads, sickles, needles, and horseshoes. From the 9th-8th centuries, the importance of leafy double-edged bronze arrowheads in the composition of weapons increased. Stone molds for making bow 
CURRENT RESEARCH JOURNAL OF HISTORY 2(5): 42-46, May 2021

DOI: https://doi.org/10.37547/history-crjh-02-05-12

ISSN 2767-472X

(C)2021 Master Journals

\section{Crossref dof 80 Google}

Accepted 25 $5^{\text {th }}$ May, 2021 \& Published 30th May, 2021

tips were found at Yakkaparson [4]. This evidence testifies to the activity of bronze casters, the work of degreasing.

Remains of ammunition with hooks made of stone, bone, bronze and wood were found in the tombs of Sakarchaga in the 7th century BC [14]. More than 50 bronze bullets were found at Kuyisoy 2. Such a bow axis is called the arrowhead of the Scythian or Sak tribes. They are widespread in the monuments of cattle breeders living in the steppes and steppe-forest areas of the Volga, Southern Urals, Kazakhstan, Western Siberia [2].

Daggers and long knives were made of iron. Iron tools played an important role in the processing of stone, bone and wood. The data found in this regard indicate the prevalence of iron products in the economic and military spheres of the early Saks. Aware of this, Herodotus wrote that ironware was not used in the household of the Massagets because the metal was "not found at all" in their country [3]. In fact, this conclusion did not correspond to historical vocabulary.

The presence of weapons and horse equipment among the burial equipment in the tombs of the Saxon men is a special feature. Horse equipment was also found in the graves of women riders [10]. They consist of bronze domes adorning buckle, and horse harness. The bronze buckles and domes feature images of birds of prey, deer, tigers, and pigs. They consist of images of a mythical bird-headed creature typical of the fine arts of steppe cattle-breeders, such as the griffin and the tortoise tearing off the hooves of wild animals such as a tiger, in a style known as Scythian-Siberian [1].

Burial equipment in the tombs of Sak women includes jewelry. They consist of bracelets, earings and necklaces. Bronze, silver, gold, semiprecious and precious gemstones were used in the jewelry art of the steppe tribes. Most of the finds are necklaces of different colors.
They are made of turquoise, lapis lazuli, sardines and limestone. The necklaces are geometric (cylindrical, rhombic) in shape, made of sardine stone with a dazzling, light red-orange color, turquoise beads are blue, lapis lazuli necklaces are blue [11].

Traces of processing of turquoise mineral stone in the conditions of domestic handicrafts were found at the settlement of Kuyisay 2. This is evidenced by insufficiently processed necklaces and their fragments [12].

Turqoise deposits are located in the Sultan Uvays Mountains and Kyzyl-Kum [13]. This mineral rock was used only in the jewelry industry. For example, the palaces of ancient Persian kings were decorated with gold and precious stones. According to records of the construction of the palace of Darius I in Suza, gold was delivered from Bactria to decorate the doors and walls of the palace, glittering stones from Sogdiana lapis lazuli and sardines, and turquoise from Khorezm [5]. However, the calligrapher who wrote these inscriptions made a mistake somewhere. In fact, the deposits of lapis lazuli are not in Sogdiana, they are located in the Badakhshan mountains of Bactria.

\section{Conclusion}

As a conclusion of the above mentioned ideas, the following should be stated:

I. The transition to a form of production farming in the Aral Sea region began much later than in the southern regions of Central Asia. This phenomenon is marked by the uneven socioeconomic development of the tribes located in different natural-geographical regions.

From the earliest times of history, the abundance of food products assimilated in the Lower Amu Darya and Lower Syr Darya regions, that is, the products available in nature, have met the needs of hunters and fishermen communities. Thus, the 
CURRENT RESEARCH JOURNAL OF HISTORY 2(5): 42-46, May 2021

DOI: https://doi.org/10.37547/history-crjh-02-05-12

ISSN 2767-472X

(C)2021 Master Journals

\section{Crossref dof 81 Google}

Accepted 25th May, 2021 \& Published 30 th May, 2021

productive forces and inventions in the economic and cultural spheres are underdeveloped. These circumstances determined the period of formation of the production economy.

II. During the Bronze Age, as a result of the development of the social division of labor in different regions of Central Asia and the cultural influence of the primary centers of economic and technological progress, various innovations in the life and lifestyle of the Aral Sea population were revealed. Therefore, during this period, the communities of the Southern Aral Sea region consisted of "cattle-farmers" or "shepherdsfarmers", and the tribes of the Eastern Aral Sea region consisted of groups of cattle-breeders. According to the results of new research, the views on the leadership of the form of agriculture and animal husbandry in the Southern Aral Sea region have not been proven and the agricultural sector formed an auxiliary branch of the economy until the 6th century BC.

III. The following economic and cultural types have been developed in the Aral Sea region since the Bronze Age:

1. Approximately 16 th-20th centuries BC, cattlebreeding and agriculture (lower Amu Darya, Southern Aral Sea), cattle-breeding (lower Syr Darya, Eastern Aral Sea).

2. The 10th-8th (or 9th-8th) centuries BC, Amirabad livestock-farming culture of the Southern Aral Sea region, North Tagisken steppe cattle breeders of the Eastern Aral Sea.

3. The 7th-6th centuries BC, Sariqamish region settled cattle breeders, Kuyisay culture and Sakarchaga first Sak nomads, the emergence of the Kozalikir culture of settled herders and peasants at the turn of the 7th-6th centuries BC.

The first seasonal migratory Saks culture in the Lower Syr Darya Basin.

4. The 5th-4th centuries BC, the predominance of crop culture in the Southern Aral Sea, the settlement of Saks in the Eastern Aral Sea.

The system of chronology mentioned above is based on data from archeology and early written sources and reflects the historical reality in evidence.

\section{ReFERENCES}

1. Artamanov M.I. Skifo-sibirskoe iskusstvo zverinnogo stilya (osnovnie etapy i napravleniya) // Problemy skifskoy arkheologii. MIA. №177. - M., 1971.

2. Akishev K.A. Saki aziatskie i skifi yevropeyskie: obshee i osobennoe v kulture // Arkheologicheskie issledovaniya v Kazakhstane. Alma-Ata, 1973. - P. 49; Avanesova N.A. K voprosu o bronzovukh strelax plemen epokhi bronzy // Materialy po arkheologii Uzbekistana. Tr. Samarkandskogo gosuniversiteta. Vip. 270. - Samarkand, 1975. - P. 38.

3. Herodotus. Book. I, 215.

4. Itina M.A. Poselenie Yakke-Parsan 2 (raskopki 1958-1959 у.) // MXE. - M., 1963. - P. 118-119.

5. Khrestomatiya po istorii Drevnego Vostoka. Nadpis Dariya I o soorujenii d vorsa v Suzakh // Perevod V.I. Abaeva. - M.: Vysshaya shkola, 1980. Part II. - P. 38-39.

6. Matyakubov H. Khorazm vohasi bronza asri va ilk temir davri tarixi. - Tashkent, 2017. P. 23.

7. Matyakubov H. The above mentioned source. ᄀ- P. 120.

8. Matyakubov H. Khorazm vohasi bronza asri ... P. 111.

9. Tolstov S.P. Raboty Khrezmskoy arxeologoetnograficheskoy ekspedisii 1951-1954 gg. // Voprosy istorii. - M., 1955. №3. - P. 173- 
180; Itina M.A. Raskopki stoyanki Tazabaghyabskoy kultury v 1957 g. // MXE. - M., 1960. Vip. 4. - P. 82-103; the same author. Raskopki mogilnika tazabaghyabskoy kultury Kokcha 3 // MXE. - M., 1961. Vip. 5. - P. 3-96; the same author. 0 meste tazabaghyabskoy kultury sredi kultur stepnoy bronzi // SE. - M., 1967. №2. - P. 62-74.

10. Vishnevskaya O.A. Kultura sakskikh plemen nizovev Sirdari v VII - V vv. do n. e. // Tr. XAEE. Volume 8. - M., 1973. - P. 72-73; Yablonskiy L.T. Saki Yujnogo Priaralya (arkheologiya i antropologiya mogilnikov). M.: Institute of archeology RAN, 1996. - P. 100.

11. Vishnevskaya O.A. Kultura sakskikh plemen ... P. 82-84.

12. Vaynberg B.I. Kuyusayskaya kultura rannego jeleznogo veka v Prisarikamishskoy delte Amudari // Uspekhi sredneaziatskoy arkheologii. - L.: Nauka, 1975. - P. 45-46.

13. Vinogradov A.V., Lopatin S.V., Mamedov E.D. Kizilkumskaya biryuza // SE. - M., 1965. №2.

14. Yablonskiy L.T. Saki Yujnogo Priaralya (arxeology and anthropology mogolnikov). M.: Institute arxeology, 1996. - P. 34.

15. Shomirzaev M.Kh. National handicrafts of Uzbekistan and its social - economic significance. (2020). European Journal of Research and Reflection in Educational Sciences, 8 (8), Part III. 129-138. 